\title{
PENGARUH MOTIVASI DAN DISIPLIN KERJA TERHADAP PRODUKTIVITAS KERJA KARYAWAN UNIVERSITAS KOMPUTER INDONESIA
}

\section{THE EFFECT OF MOTIVATION AND WORK DISCIPLINE ON EMPLOYEE WORK PRODUCTIVITY IN INDONESIA COMPUTER UNIVERSITY.}

\author{
Hadi Purnomo \\ Dr. Rahma Wahdiniwaty, Dra., M.Si.
}

Fakultas Pascasarjana Universitas Komputer Indonesia (UNIKOM)

\begin{abstract}
ABSTRAK
Saat ini dunia pendidikan sangat pesat pertumbuhannya,untuk itu dibutuhkan kualitas sumber daya manusia yang baik guna dapat bersaing.Perusahaan selalu bertujuan untuk meningkatkan produktivitas kerja karyawannya,tingkat efisensi,efektif dan waktu yang rendah mengakibatkan produktivitas kurang optimal.Hal ini dipengaruhi oleh kurangnya motivasi kerja sehingga dapat menurunkan tingkat disiplin kerja karyawan. Oleh karena itu berbagai cara yang dilakukan oleh perusahaan sehingga dapat memenuhi beberapa faktor yang mengakibatkan peningkatan atau penurunan produktivitas kerja karyawan. Dalam penelitian ini penyebab meningkat atau menurunnya produktivitas kerja karyawan peneliti mengamati 2 (dua ) faktor yaitu motivasi dan disiplin kerja.

Adapun tujuan dalam penelitian ini untuk mengetahui motivasi dan disiplin kerja terhadap produktivitas kerja karyawan Universitas Komputer Indonesia.Dimana produktivitas kerja karyawan rendah,motivasi kurang optimal dan displin kerja yang rendah.

Penelitian ini menggunakan metode analisis kuantitatif dengan jumlah responden 152 orang responden dari seluruh jumlah populasi sebanyak 152 orang yang merupakan karyawan tetap di Universitas Komputer Indonesia. Data dikumpulkan dengan observasi dan kuisioner dan studi dokumentasi. Metode analisis yang digunakan adalah deskriptif dan verifikatif. Pengolahan data dengan SEM dan perangkat lunak Lisrel 8.7.

Hasil penelitian secara simultan menunjukkan bahwa motivasi dan disiplin kerja berpengaruh signifikan terhadap produktivitas kerja karyawan. Dan secara parsial motivasi berpengaruh positif dan signifikan terhadap produktivitas kerja,dan disiplin kerja berpengaruh posistif dan signifikan terhadap produktivitas kerja karyawan.
\end{abstract}

Kata Kunci : Motivasi,Disiplin,Produktivitas Kerja 


\begin{abstract}
At present, the world of education is grown rapidly, that is why a quality of good human resources are needed for competition. The company aims to increase employee work productivity or performance, level of efficiency, effectiveness and less time decrease the employee performances. Lack of work motivation caused the level of employee discipline. Therefore, various ways are carried out by the company to face several factors that lead to an increase or decrease in employee work productivity. In this study, there are some factors the cause of the increase or decrease in employee work productivity, researchers observed 2 (two) factors, namely motivation and work discipline.
\end{abstract}

The purpose of this research is to find out the motivation and discipline of work on the work productivity of Indonesian Computer University employees. Where the employee's work productivity is low, motivation is not optimal and work discipline is low.

This study uses a method of quantitative analysis with the number of respondents 152 respondents from the entire population of 152 people who are permanent employees at the Indonesian Computer University. Data were collected by observation and questionnaire and documentation study. The analytical method used is descriptive and verification. Data processing with SEM and Lisrel 8.7 software.

Simultaneous research results show that work motivation and discipline have a significant effect on employee work productivity. And partially motivation has a positive and significant effect on work productivity, and work discipline has a positive and significant effect on employee work productivity.

Keywords: Motivation, Discipline, Work Productivity 


\section{PENDAHULUAN}

Dunia pendidikan saat ini berkembang sangat pesat,persaingan antar institusi pendidikan bukan hanya dari institusi dalam negeri tetapi juga datang institusi dari laur negeri,hal tesebut merupakan salah satu yang harus dipertimbangkan dalam menetukan strategi-strategi yang akan diambil dalam organisasi,untuk itu institusi pendidikan dituntut agar dapat menyesuaikan dengan kondisi saat ini.

Dalam rangka meningkatkan kualiats perguruan tinggi di Indonesia,diperlukan peningkatan kualitas sumber daya manusia dalam hal ini tenaga pendidikan dan tenaga kependidikan dalam menunjang peningkatan mutu di dunia pendidikan saat ini.Tenaga pendidik dan tenaga kependidikan merupakan faktor yang sangat berpengaruh dalam tingginya persaingan antar perguruan tinggi saat.

Produktivitas karyawan sangat dibutuhkan dalam meningkatkan kualitas anak didik sehingga dapat mencapai tujuan

Program Studi Magister Manajemen

Fakultas Pascasarjana

Universitas Komputer Indonesia perusahaan secara efektif dan efisien. Produktivitas karyawan yang tinggi akan menghasilkan pencapaian yang maksimal dalam pekerjaan. Dari observasi yang dilakukan,tingkat penyelesaian pekerjaan karyawan di Universitas Komputer Indonesia memiliki tingkat penyelesaian yang dilakukan tidak tepat waktu dan kurang mencapai target pekerjaan.

Salah satu faktor yang mempengaruhi produktivitas kerja adalah disiplin kerja karyawan. Tingkat kedisplinan pegawai dalam suatu organisasi dapat dilihat salah satunya dari tingkat ketepatan waktu masuk kerja.Universitas Komputer Indonesia memiliki jumlah karyawan sebanyak 152 karyawan tetap,yang dibagi beberapa bagian yaitu staff sekertariat program studi,staff non sekertariat program studi,satpam dan tenaga kebersihan.

Tinggi rendahnya displin kerja para pegawai pada umumnya akan mempengaruhi produktivitas suatu organsasi.Untuk meningkatkan Disiplin kerja karyawan dilingkungan Universitas Komputer indonesia dibutuhkan motivasi yang baik,untuk mendorong melaksanakan pekerjaan dengan baik. Hal-hal yang harus 
diperhatikan yaitu masalah kesejahteraan,bonus serta penghargaan atas kinerja yang baik.Hal tersebut diatas berkaitan dengan motivasi kerja karyawan,yakni kondisi yang menjadikan karyawan mau bekerja dengan segala kemampuannya. Untuk mencari kebenaran tersebut maka peneliti bermaksud untuk mengadakan penelitian dengan judul "Pengaruh Motivasi dan Disiplin kerja Karyawan terhadap Produktivitas Kerja Karyawan Universitas Komputer Indonesia"

\section{KAJIAN PUSTAKA}

\section{Motivasi}

Motivasi merupakan kondisi mental yang mendorong aktivitas dan memberi energi yang mengarah kepada pencapaian kebutuhan, memberi kepuasan ataupun mengurangi ketidak seimbangan. (Beredom,Garry A. Stainer 2006 dalam Sri Widodo 2015:164)

Gibson (2013:165) menyatakan bahwa motivasi adalah kekuatan yang mendorong seorang karyawan yang menimbulkan dan mengarahkan perilaku.

\section{Disiplin}

Siagian (2013:305) mendefinisikan displin kerja adalah suatu bentuk pelatihan

Program Studi Magister Manajemen

Fakultas Pascasarjana

Universitas Komputer Indonesia

\section{Jurnal Ilmiah Magister Manajemen}

yang brusaha memperbaiki dan membentuk pengetahuan,sikap dan perilaku pegawi sehingga para pegawai tersebut secara sukarela beruasah bekerja kooperatif dengan para pegawai yang lain serta meningkatkan prestasi kerja.Sastrohardiwiryo (2002:130) dalam S.L Mandey (2014:1594) menyatakan disiplain adalah suatu sikap menghormati,menghargai, patuh dan taat terhadap peraturan-peraturan yang berlaku baik yang tertulis maupun tidak terulis serta sanggup menjalankan dan tidak mengelak untuk menerima sanksisanksi apabila dia melanggar tugas dan wewenang yang diberikan kepadanya.

\section{Produktivitas}

Ardana,(2012:270) menyatakan produktivitas sebagai perbandingan antara hasil yang dicapai dengan keseluruhan daya atau faktor produksi yang dipergunakan.

Produktivitas dapat diartikan sebagai tingkat perbandingan antara keluaran (output) dengan masukan (input), (Bernardin,Russke 1993 dalam sri Widodo 2015:4).

\section{Keterkaitan antar variabel}


1. Keterkaitan Motivasi dengan Produktivitas kerja

Roni Faslah (2013:50) menerangkan bahwa terdapat pengaruh yang positif dan signifikan motivasi terhadap produktivitas kerja karyawan pada PT. Kabelindo Murni.Tbk

2. Keterkaitan Disiplin kerja dengan Produktivitas kerja

Penelitian Shannon C.Y Assagaf (2015:648) menunjukkan disiplin secara parsial berpengaruh signifikan terhadap produktivitas pegawai dinas pendapatan daerah kota Manado

METODE

\section{Objek Penelitian}

Objek yang penulis gunakan dalam penelitian ini adalah untuk mengetahui pengaruh motivasi dan disiplin kerja terhadap produktivitas kerja karyawan Universitas Komputer Indonesia,dengan jumlah responden sebanyak 152 orang.

\section{Metode Penelitian}

Metode yang digunakan dalam penelitian ini adalah metode deskriptif dan verifikatif.Penelitian ini menggunakan metode

\section{Jurnal Ilmiah Magister Manajemen}

survey.Pengolahan data menggunakan

SEM dengan perangkat lunak Lisrel.

\section{Desain Penelitian}

Desain penelitian yang digunakan dalam penelitian ini yaitu penelitian kausalitas yang bertujuan menjelaskan hubungan sebab akibat antar variabel yang diteliti dengan tujuan untuk mengetahui pengaruh motivasi dan disiplin kerja terhadap produktivitas kerja karyawan Universitas Komputer Indonesia.

Tekhnik Pengumpulan Data

Pengumpulan data dilakukan dengan cara :

1. Observasi

2. Kuisioner

3. Wawancara

4. Studi literatur

\section{Uji validitas dan Reliabilitas Instrument}

\section{Uji Validitas}

Untuk melakukan pengujian validitas terhadap instrumen, dalam penelitian ini hanya ditinjau pada validitas internal. Untuk mengetahui apakah setiap butir dalam instrumen itu valid atau tidak, dapat diketahui dengan cara menghitung koefisien korelasi antara skor butir (dipandang sebagai $X$ ) dengan skor total (dipandang sebagai Y). Dalam penelitian ini 
digunakan korelasi korelasi person's product moments hasil perhitungan dengan $r$ tabel.jika $r$ hitung lebih besar dari r tabel berati korelasi person's product moments untuk tiap butir pernyataan ada valid ( $1^{\prime}$ hitung $>1$ tabel Valid), karena data pada penelitian ini memiliki skala ukur ordinal.

Nilai validitas pada dasarnya adalah nilai korelasi. Oleh karena itu, untuk menguji validitas dilakukan dengan teknik korelasi item total yang merupakan dasar dari korelasi pearson.

\section{Uji Reabilitas}

Uji Reliabilitas adalah suatu pengujian yang dipergunakan untuk mengetahui sejauhmana hasil suatu pengukuran dapat dipercaya. Hasil pengukuran dapat dipercaya apabila dipergunakan dalam beberapa kali pengukuran terhadap kelompok subyek yang sama diperoleh hasil yang relatif sama, selama aspek yang diukur dalam diri subyek tidak berubah.

Menurut (2012:156), relibilitas berkenaan dengan derajat konsoistensi dan stabilitas data atau temuan,suatu data dinyatakan reliabel apabila dua atau lebih peneliti menyatakan hasil yang sama,atau peneliti yang sama di waktu yang berbeda.

\section{Pengujian Hipotesis}

Dalam LISREL tidak terdapat nilai signifikansi yang langsung dapat memberi tahu apakah hubungan antara suatu variabel dengan variabel lainnya adalah signifikan. Pada setiap estimasi dalam lisrel, terdapat tiga informasi yang sangat berguna: yaitu koefisien regresi, standar error dan nilai t. Standar error digunakan untuk mengukur ketepatan dari setiap estimasi parameter.

Untuk mengetahui signifikan tidaknya hubungan antar variabel, maka nilai t harus lebih besar dari t-tabel pada level tertentu yang tergantung dari ukuran sampel dan level signifikansi.

Pada taraf signifikansi 0,05 maka nilai $t$ tabel adalah $\pm 1,960$, berikut merupakan hipotesa yang digunakan:

$\mathrm{H}_{0} \quad$ : variabel eksogen (X) tidak memberikan pengaruh signifikan terhadap variabel endogen $(\mathrm{Y})$

$\mathrm{H}_{1}$ : variabel eksogen (X) tidak memberikan pengaruh signifikan terhadap variabel endogen $(\mathrm{Y})$

Kriteria uji:

- $\quad$ Apabila $\mathrm{t}$ hitung $>\mathrm{t}$ tabel maka $\mathrm{Hi}$ diterima dan Ho ditolak 
- Apabila $\mathrm{t}$ hitung $\leq \mathrm{t}$ tabel maka $\mathrm{H}_{\mathrm{o}}$ diterima dan Hi ditolak

\section{Uji F Statistik}

Uji F statistik adalah untuk menguji pengaruh variabel bebas terhadap variabel tidak bebas secara keseluruhan.

Berdasarkan identifikasi masalah yang dikemukakan sebelumnya,maka dalam penelitian ini mengaukan hipotesi sebagai beriku :

Hipotesis simultan antar variabel bebas budaya organisasi,motivasi dan disiplin kerja terhadap produktivitas kerja karyawan.

$\mathrm{H}_{0}$ : $\quad$ Motivasi $\left(X_{1}\right)$, dan Disiplin Kerja $\left(X_{2}\right)$ secara bersamasama tidak memiliki pengaruh signifikan terhadap variabel Produktivitas $(\mathrm{Y})$.

$\mathrm{H}_{1}$ : Motivasi $\left(\mathrm{X}_{1}\right)$, dan Disiplin Kerja $\left(X_{2}\right)$ secara bersamasama memiliki pengaruh signifikan terhadap variabel Produktivitas ( $\mathrm{Y}$ )

Adapun hipotesa umum untuk masing-masing pengujian adalah sebagai berikut:

$\mathrm{H}_{0} \quad$ : tidak terdapat pengaruh signifikan
$\mathrm{H}_{1} \quad$ : terdapat pengaruh signifikan

Kriteria uji:

- $\quad$ Tolak Ho jika $\mathrm{t}$ hitung $\geq \mathrm{t}$ tabel atau $\mathrm{t}$ hitung $\leq-\mathrm{t}$ tabel

- $\quad$ Terima Ho jika t hitung < t tabel atau $\mathrm{t}$ hitung $\geq-\mathrm{t}$ tabel Pada tingkat signifikansi $0,05 \quad(5 \%)$ maka nilai t tabel adalah 1,96.

\section{HASIL DAN PEMBAHASAN}

\section{Identitas Responden}

Berikut ini merupakan tabel identitas responden:

Identitas Responden

\begin{tabular}{|c|c|c|}
\hline Kategori & Jumlah & Persentase \\
\hline \multicolumn{3}{|l|}{ Usia } \\
\hline$<31$ tahun & 25 & 16,4 \\
\hline 31 - 40 tahun & 94 & 61,8 \\
\hline 41 - 50 tahun & 29 & 19,1 \\
\hline$>50$ tahun & 4 & 2,6 \\
\hline Total & 152 & 100 \\
\hline \multicolumn{3}{|l|}{ Jenis Kelamin } \\
\hline Pria & 72 & 47,4 \\
\hline Wanita & 80 & 52,6 \\
\hline Total & 152 & 100 \\
\hline \multicolumn{3}{|l|}{ Pendidikan } \\
\hline SD/SMP & 6 & 3,9 \\
\hline SMU & 29 & 19,1 \\
\hline $\mathrm{D} 3 / \mathrm{S} 1$ & 113 & 74,3 \\
\hline S2/S3 & 4 & 2,6 \\
\hline
\end{tabular}




\section{BIDANG ILMU MANAJEMEN}

Total

152

100

Lama Bekerja

0-2 tahun

19

12,5

3-5 tahun

6-8 tahun

$>8$ tahun

Total

Sumber : Data diolah 2018

Berdasarkan tabel di atas, sebagian besar responden berusia 31 tahun hingga 40 tahun, yaitu sebanyak 94 responden $(61,8 \%)$; terbanyak berikutnya adalah yang berusia 41 tahun hingga 50 tahun yaitu sebanyak 29 responden $(19,1 \%)$; kemudian yang berusia kurang dari 31 tahun sebanyak 25 responden (16,4\%); dan paling sedikit adalah yang berusia lebih dari 50 tahun yaitu sebanyak 4 responden $(2,6 \%)$.

Berdasarkan Jenis Kelamin, sebagian besar responden berjenis kelamin wanita yaitu sebanyak 80 responden $(52,6 \%)$ dan yang berjenis kelamin pria sebanyak 72 responden $47,4 \%$.

Berdasarkan Pendidikan, sebagian besar responden memiliki pendidikan D3/S1 yaitu sebanyak 113 responden $(74,3 \%)$, kemudian yang memiliki pendidikan SMU sebanyak 29 responden $(19,1 \%)$, yang memiliki pendidikan SD/SMP sebanyak 6 responden (3,9\%), dan yang memiliki pendidikan S2/S3 sebanyak 4 responden $(2,6 \%)$

Berdasarkan lama bekerja, mayoritas responden telah bekerja selama lebih dari 8 tahun yaitu sebanyak 95 responden $(62,5 \%)$, sedangkan sisanya telah bekerja selama 6 tahun hingga 8 tahun,selama 3 tahun hingga 5 tahun, dan kurang dari 3 tahun masing-masing sebanyak 19 responden $(12,5 \%)$.

\section{Rekapitulasi Tanggapan Responden Tentang Motivasi (X1)}

\section{Rekapitulasi Tanggapan Responden Tentang Motivasi}

Rekapitulasi Tanggapan Responden Tentang Motivasi

\begin{tabular}{|c|c|c|c|}
\hline Indikator & Skor & Mean & Kategori \\
\hline Gaji / Upah & 810 & 2,66 & $\begin{array}{l}\text { Cukup } \\
\text { Baik }\end{array}$ \\
\hline Bonus & 1045 & 3,44 & Baik \\
\hline Penghargaan & 1185 & 3,90 & Baik \\
\hline Kondisi Kerja & 1175 & 3,87 & Baik \\
\hline Tanggung Jawab & 1136 & 3,74 & Baik \\
\hline Total dan rata-rata & 5351 & 3,52 & Tinggi \\
\hline
\end{tabular}

Secara keseluruhan hasil pengolahan yang disajikan pada tabel 4.13 menghasilkan skor sebesar 810 dan nilai rata-rata sebesar 2,66 untuk indikator 
gaji/upah,untuk indikator bonus menghasilkan skor 1045 dengan nilai ratarata 3,44 ,indikator penghargaan mendapatkan skor 1185 dengan nilai ratarata 3,90,selanjutnya indikator kondisis kerja mendapatkan skor 3,87 dengan nilai rata-rata 3,87 dan untuk indikator tanggungjawab sebesar 1136 dengan ratarata 3,74.Total keseluruhan indikator sebesar 5351 dengan dengan rata-rata sebesar 3,52. Nilai rata-rata tersebut dimasukkan ke dalam garis kontinum, yang pengukurannya ditentukan dengan cara berikut :

- Nilai Indeks Maksimum = 5

- Nilai Indeks Minimum $\quad=1$

- Jarak Interval = [nilai maksimum - nilai minimum] $: 5$ $=[5-1]: 5$

$$
=0,8
$$

- Rata-rata keseluruhan $=$

- [(total skor) : (jumlah responden x jumlah pertanyaan)]

$=[(5351):(152 \times 10)]=3,52$

Dari perhitungan dalam tabel menujukkan skor yang diperoleh adalah 5351 dengan rata-rata sebesar 3,52. Maka dari itu dapat kita simpulkan bahwa Tanggapan responden mengenai Motivasi karyawan Unikom secara keseluruhan berada dalam kategori baik.Ini dikarenakan perusahaan telah melakukan apa yang diinginkan oleh karyawan dalam pemberian motivasi oleh perusahaan,dengan melihat hasil

Program Studi Magister Manajemen

Fakultas Pascasarjana

Universitas Komputer Indonesia responden beberapa indikator motivasi yang hampir semua jawaban responden menunjukkan kriteria yang tinggi.

\section{Rekapitulasi Tanggapan Responden}

\section{Tentang Disiplin Kerja (X2)}

\section{Rekapitulasi Tanggapan Responden}

Tentang Disiplin Kerja

\begin{tabular}{|c|c|c|c|}
\hline Indikator & Skor & Mean & Kategori \\
\hline Ketepatan Waktu & 1171 & 3,85 & Baik \\
\hline $\begin{array}{c}\text { Ketaatan Terhadap Peraturan } \\
\begin{array}{c}\text { Melaksankan Tugas dan } \\
\text { Kewajiban }\end{array}\end{array}$ & 1821 & 3,99 & Baik \\
\hline $\begin{array}{c}\text { Total dan rata-rata Disiplin } \\
\text { Kerja }\end{array}$ & $\mathbf{4 2 1 4}$ & $\mathbf{3 , 9 5}$ & Baik \\
\hline
\end{tabular}

Sumber : Data diolah 2018

Secara keseluruhan hasil pengolahan yang disajikan pada tabel menghasilkan skor total sebesar 4241 dengan dengan rata-rata sebesar 3,95. Nilai rata-rata tersebut dimasukkan ke dalam garis kontinum, yang pengukurannya ditentukan dengan cara berikut :

\footnotetext{
- Nilai Indeks Maksimum = 5

- Nilai Indeks Minimum = 1

- Jarak Interval = [nilai maksimum - nilai minimum $]: 5$ $=[5-1]: 5$ $=0,8$
}

- Rata-rata keseluruhan = 
[(total skor) : (jumlah responden x jumlah pertanyaan)]

$$
\begin{aligned}
& =[(4241):(152 \times 7)] \\
& =3,95
\end{aligned}
$$

Dari perhitungan menujukkan indikator ketepatan waktu mendapatkan skor 1171 dengan nilai rata-rata 3,85, untuk indikator ketaatan terhadap peraturan mendapatkan skor sebesar 1821 dengan nilai rata-rata sebesar 3,99 dan untuk indikator melaksanakan tugas dan kewajiban dengan skor 1222 dengan ratarata 4,02.Total skor yang diperoleh adalah 4241 dengan rata-rata sebesar 3,95. Maka dari itu dapat kita simpulkan bahwa Tanggapan responden mengenai Displin Kerja karyawan Unikom secara keseluruhan berada dalam kategori baik.

\section{Rekapitulasi}

Tanggapan

\section{Responden Tentang Produktivitas ( $Y$ )}

Rekapitulasi Tanggapan Responden mengenai

Produktivitas (Y)

\begin{tabular}{|c|c|c|c|}
\hline Indikator & Skor & Mean & Kategori \\
\hline Efektif & 1191 & 3,92 & Baik \\
\hline Efisien & 1208 & 3,97 & Baik \\
\hline Waktu & 1231 & 4,05 & Baik \\
\hline $\begin{array}{c}\text { Total dan rata-rata } \\
\text { Produktivitas }\end{array}$ & 3630 & $\mathbf{3 , 9 8}$ & Tinggi \\
\hline \\
Sumber : Data diolah 2018 & & \\
\hline
\end{tabular}

\section{Jurnal Ilmiah Magister Manajemen}

Secara keseluruhan hasil pengolahan yang disajikan pada tabel menghasilkan skor total sebesar 3630 dengan dengan rata-rata sebesar 3,98. Nilai rata-rata terßebut dimasukkan ke dalam garis kontinum, yang pengukurannya ditentukan dengan cara berikut :

\footnotetext{
- Nilai Indeks Maksimum = 5

- Nilai Indeks Minimum = 1

- Jarak Interval

= nilai maksimum - nilai minimum] $: 5$
}

$$
\begin{aligned}
& =[5-1]: 5 \\
& =0,8
\end{aligned}
$$

- Rata-rata keseluruhan = [(total skor) : (jumlah responden x jumlah pertanyaan)] $=[(3630):(152 \times 6)]$

$$
=3,98
$$

Dari perhitungan menujukkan skor yang diperoleh adalah 3630 dengan ratarata sebesar 3,98. Maka dari itu dapat kita simpulkan bahwa Tanggapan responden mengenai Produktivitas ( $\mathrm{Y}$ ) Karyawan Unikom secara keseluruhan berada dalam kategori tinggi.

\section{Uji Normalitas}


Asumsi yang paling fundamental dalam analisis multivariate adalah normalitas, yang merupakan bentuk suatu distribusi data pada suatu variabel metrik tunggal dalam menghasilkan distribusi normal. Suatu distribusi data yang tidak membentuk distribusi normal, maka data tersebut tidak normal, sebaliknya data dikatakan normal apabila ia membentuk suatu distribusi normal. Apabila asumsi normalitas tidak dipenuhi dan penyimpangan normalitas tersebut besar, maka seluruh hasil uji statistik adalah tidak valid karena perhitungan uji-t dan lain sebagainya dihitung dengan asumsi data normal (Ghozali, 2014:37). Berdasarkan hasil Test of Multivariate Normality for Continuous Variables tersebut di atas, model secara keseluruhan menunjukkan memenuhi asumsi normalitas, dimana $p$-value Skewness and Kurtosis sebesar 0,060 lebih tinggi dari 0,05 .

\section{Uji Multikolinieritas}

Asumsi berikutnya yang diuji adalah multikolinieritas. Multikolinieritas artinya ada korelasi yang sangat tinggi antara variabel laten eksogen. Multikolinieritas dapat dideteksi dengan metode korelasi, jika terdapat ternilai korelasi yang lebih tinggi dari 0,8 artinya terdapat multikolinieritas antar variabel eksogen.

Nilai korelasi antara Motivasi (X1) dan Disiplin (X2) adalah 0,46. Karena semua nilai korelasi antara variabel eksogennya lebih rendah dari 0,8 sehingga disimpulkan tidak terdapat multikolinieritas.

\section{Model Pengukuran}

Evaluasi ini dilakukan terhadap setiap konstruk atau model pengukuran (hubungan antara variabel laten dengan variabel teramati) secara terpisah melalui validitas dan reliabilitas dari model pengukuran. suatu variabel dikatakan mempunyai validitas yang baik terhadap konstruk atau variabel latennya jika nilai muatan faktornya standarnya (standardized loading factor) lebih besar dari atau sama dengan nilai kritis sebesar 0,50 atau nilai $t$ muatan faktornya standarnya (standardized loading factor) lebih besar dari atau sama dengan nilai kritis sebesar 1,96 . Sedangkan pengukuran reliabilitas menggunakan construct reliability measure dan average variance extracted dengan rumus sebagai berikut :

$$
\text { Construct Reliability }=\frac{\left(\sum \text { Standardized Loading }\right)^{2}}{\left(\sum \text { Standardized Loading }\right)^{2}+\sum \varepsilon_{j}}
$$




$$
\text { Variance Extracted }=\frac{\sum \text { Standardized Loading }^{2}}{\sum \text { Standardized Loading }^{2}+\sum \varepsilon_{j}}
$$

di mana standardized loading dapat diperoleh secara langsung melalui output aplikasi program LISREL, dan $\varepsilon_{j}$ adalah measurement error untuk setiap indikator atau variabel teramati. Tingkat cut-off untuk dapat mengatakan bahwa construct reliability baik adalah lebih besar dari 0,60, sedangkan tingkat cut-off untuk dapat mengatakan bahwa average variance extracted baik adalah lebih besar dari 0,50.

Terdapat pengaruh signifikan Motivasi $\left(\mathrm{X}_{1}\right)$ terhadap Produktivitas $(\mathrm{Y})$

Hipotesa Statistik:

$\mathrm{H}_{01} \quad$ : Motivasi $\left(\mathrm{X}_{1}\right)$ tidak berpengaruh signifikan terhadap Produktivitas $(\mathrm{Y})$

$\mathrm{H}_{12}$ : Motivasi $\left(\mathrm{X}_{1}\right)$ berpengaruh signifikan terhadap Produktivitas (Y)

Dari hasil perhitungan diperoleh nilai koefisien jalur $\rho_{y \times 2}=0,30$ dengan nilai $t$ hitung $=3,71$. Nilai koefisien jalur diatas menunjukkan hubungan yang searah antara Motivasi $\left(\mathrm{X}_{1}\right)$ dan Produktivitas $(\mathrm{Y})$, karena bernilai positif $(0,30>0)$. Artinya jka Motivasi meningkat maka Produktivitas akan meningkat, begitu juga sebaliknya.

Nilai pada $\mathrm{t}$ tabel dengan tingkat signifikansi 0,05 adalah $\pm 1,96$ sehingga $\mathrm{t}$ thitung $(3,71)>\mathrm{t}$ tabel $(1,96)$. Dengan demikian koefisien signifikan, $\mathrm{H}_{01}$ ditolak dan $\mathrm{H}_{12}$ diterima, artinya terdapat pengaruh signifikan Motivasi $\left(\mathrm{X}_{1}\right)$ terhadap Produktivitas $(\mathrm{Y})$.

\section{Terdapat pengaruh Signifikan Disiplin} Kerja $\left(\mathrm{X}_{2}\right)$ terhadap Produktivitas $(\mathrm{Y})$

Hipotesa Statistik:

$$
\begin{array}{ccr}
\mathrm{H}_{02} \quad \text { : } & \text { Disiplin Kerja }\left(\mathrm{X}_{2}\right) \quad \text { tidak } \\
& \text { berpengaruh } & \text { signifikan } \\
& \text { terhadap Produktivitas }(\mathrm{Y})
\end{array}
$$
nilai koefisien jalur $\rho_{y \times 1}=0,36$ dengan nilai $t$ hitung $=4,58$. Nilai koefisien jalur diatas menunjukkan hubungan yang searah antara Disiplin Kerja $\left(\mathrm{X}_{2}\right)$ dan Produktivitas $(\mathrm{Y})$, karena bernilai positif $(0,36>0)$. Artinya jka Disiplin Kerja meningkat maka Produktivitas akan meningkat, begitu juga sebaliknya.

Nilai pada $t$ tabel dengan tingkat signifikansi 0,05 adalah $\pm 1,96$ sehingga $\mathrm{t}$ thitung $(4,58)>\mathrm{t}$ tabel $(1,96)$. Dengan demikian koefisien signifikan, $\mathrm{H}_{02}$ ditolak dan $\mathrm{H}_{13}$ diterima, artinya terdapat pengaruh signifikan Disiplin Kerja $\left(X_{3}\right)$ terhadap Produktivitas (Y).

\section{KESIMPULAN}




\begin{abstract}
Dari hasil penelitian tentang pengaruh motivasi dan disiplin kerja terhadap produktivitas kerja karyawan Universitas Komputer Indonesia ,maka peneliti mengambil kesimpulan :
\end{abstract}

1. a. Motivasi karyawan Universitas Komputer Indonesia dalam kategori tinggi,dengan skor 5351 dengan nilai rata-rata 3,52 . Skor tertinggi pada indikator penghargaan dengan nilai rata-rata sebesar 3,90 dengan kategori baik sedangkan skor terendah pada indikator gaji/upah sebesar 810 dengan rata-rata 2,66 dalam kategori cukup baik.

b. Disiplin kerja Karyawan Universitas Komputer Indonesia dalam kategori baik,dengan skor sebesar 4241 dengan nilai ratarata 3,95.Skor tertinggi pada indikator melkasanakan tugas dan kewajiban sebesar 1222, dengan rata-rata 4,02 dalam ketgori baik dan skor terendah pada indikator ketepatan waktu dengan ratarata 3,85 dengan kategori baik.

c. Produktivitas kerja karywan Univeristas komputer Indonesia
dalam kategori tinggi,dengan skor 3630 dengan nilai rata-rata sebesar 3,98.Skor tertinggi pada indikator waktu sebesar 1231 dengan nilai rata-rata sebesar 4,05 dalam kategori baik dan indikator terendah pada indikator efektif dengan rata-rata 3,92 dalam kategori baik.

2 Motivasi yang dimiliki karyawan Universitas Komputer Indonesia memberikan pengaruh yang signifikan dengan arah positif terhadap produktivitas kerja karyawan. Hal ini menunjukkan apabila motivasi tinggi maka produktivitas akan tinggi.

Disiplin kerja karyawan Universitas Komputer Indonesia memberikan pengaruh yang signifikan dengan arah positif terhadap produktifitas kerja karyawan. Hal ini menunjukkan apabila disiplin kerja baik maka produktivitas akan tinggi

DAFTAR PUSTAKA

SCY.Assagaf,L.O.H.Dotulong, Pengaruh Disiplin,Motivasi dan Semangat Kerja Terhadap Produiktivitas Kerja Pegawai Dinas Pendapatan Daerah Kota Manado,Jurnal EMBA,Vol. 


\section{BIDANG ILMU MANAJEMEN}

3 No. 2,Juni 2015 Hal. 639-

649.

Gibson,Ivancevich,Donnelly.2013,Organisa

si,Jilid I.Penerbit Binarupa

Aksara.Jakarta.

Sri Widodo, 2015, PERILAKU ORGANISASI \& GLOBAL; Manggu Makmur Tanjung Lestari Bandung.

Sugiyono,2012, Statistika Untuk Penelitian,CV.Alfabet Bandung

Roni Faslah,Pengaruh Motivasi Kerja dan Disiplin Kerja Terhadap Produktivitas Kerja pada Karyawan PT. Kabelindo Murni Tbk. Jurnal pendidikan dan Ekonomi Bisnis (JPEB) Vol 1, No 2,Okrober 2013, diakses tanggal 14 Maret 2017 